\title{
Pengaruh Kesadaraan Wajib Pajak, Pelayanan Fiskus, Dan Sanksi Pajak Terhadap Kepatuhan Wajib Pajak Kendaraan Bermotor
}

\author{
Dewa Putu Gede Widyana ${ }^{1}$ \\ Fakultas Ekonomi dan Bisnis \\ Universitas Udayana, Indonesia \\ Email: dewawidyana701@yahoo.com
}

\author{
I Nyoman Wijana Asmara Putra ${ }^{2}$ \\ Fakultas Ekonomi dan Bisnis \\ Universitas Udayana, Indonesia
}

\begin{abstract}
ABSTRAK
Kepatuhan wajib pajak merupakan bentuk ketaatan dan tanggungjawab wajib pajak terhadap kewajibannya. Penelitian ini bertujuan untuk memperoleh bukti mengenai faktor-faktor yang memberikan pengaruh pada kepatuhan wajib pajak khususnya wajib pajak kendaran bemotor yang terdaftar di Kantor Bersama Samsat Kota Denpasar. Populasi penelitian sebanyak 393.598. Sampel ditentukan dengan metode purposive sampling yang jumlahnya diperoleh dengan rumus slovin sehingga diperoleh sebanyak 100 responden. Data dianalisis menggunakan regresi linear berganda. Penelitian memperoleh hasil bahwa kesadaran wajib pajak, pelayanan fiskus, dan sanksi pajak memberikan pengaruh positif pada tingkat kepatuhan wajib pajak kendaraan bermotor di Kantor Bersama Samsat Kota Denpasar.
\end{abstract}

Kata Kunci: $\quad$ Kepatuhan; Kesadaran; Fiskus; Sanksi Pajak.

\section{Effects of Taxpayer Awareness, Fiscus Services, and Tax Sanctions Against Motor Vehicle Taxpayer Compliance}

\section{ABSTRACT}

Taxpayer's compliance is a form of compliance and responsibility of taxpayers to their obligations. This study aims to obtain evidence regarding the factors that influence the taxpayer compliance, especially motor vehicle taxpayers registered in the Kantor Bersama Samsat Kota Denpasar. The study population was 393,598. The sample is determined by purposive sampling method, the amount of which is obtained by the Slovin formula so as to obtain as many as 100 respondents. Data were analyzed using multiple linear regression. The research obtained results that awareness of taxpayers, tax services, and tax sanctions had a positive influence on the level of taxpayer compliance in motorized vehicles in the Kantor Bersama Samsat Kota Denpasar.

Keywords: $\quad$ Compliance; Awareness; Fiskus; Tax Sanctions.

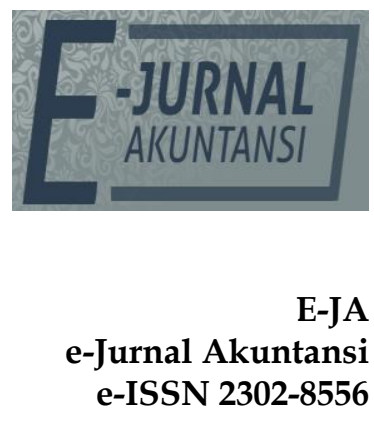

Vol. 30 No. 1

Denpasar, Januari 2020

Hal. 39-55

Artikel Masuk:

9 Juli 2019

Tanggal Diterima: 15 Agustus 2019 


\section{PENDAHULUAN}

Ekonomi Indonesia tidak dapat mewujudkan masyarakat yang sejahtera. Banyak pembangunan nasional masih kurang, bahkan publik fasilitas seperti pusat kesehatan, jalan, kantor desa dan lembaga publik lainnya yang membutuhkan untuk diperbaiki. Masyarakat sering mengeluh dan tidak puas dengan kebijakan pemerintah dalam hal pembangunan nasional. Kondisi tersebut dipengaruhi oleh ketidaktaatan dari wajib pajak itu adalah masyarakat itu sendiri dalam membayar pajak. Pajak penghasilan negara bagian itu dikembalikan ke masyarakat dalam bentuk fasilitas publik. Tetapi banyak orang tidak tahu tentang itu. Masyarakat perlu mengetahui peran pengetahuan perpajakan dengan benar (Wicaksono \& Lestari, 2017).

Pembiayaan pembangunan dan kebutuhan negara sangat bergantung pada penerimaan pajak negara dari masyarakat (Pratiwi \& Setiawan, 2014). Pembangunan infrastruktur, seperti jalan, jembatan, rumah sakit, sekolah, dan masih banyak lagi sangat dipengaruhi oleh jumlah pajak yang diterima pemerintah pusat maupun daerah. Pajak merupakan penyumbang terbesar dari penerimaan negara, selain dari hasik ekspor dan industri lainnya. Oleh karena itu, tak heran pajak menjadi hal yang efektif untuk meningkatkan kemajuan dan kesejahteraan masyarakat baik bagi pemerintah pusat ataupun pemerintah daerah. Pajak dan retribusi untuk daerah sendiri menyumbang pendapatan yang cukup besar yang dapat membantu pemerintah daerah untuk melakukan pengembangan dan pembangunan lainnya. Pemerintah daerah semakin menggalakkan kegiatan yang berpotensi menghasilkan pajak dan retribusi daerah (Susilawati \& Budiartha, 2013). Pajak dan retribusi daerah merupakan sumber pendapatan yang berguna untuk membiayai pengeluaran daerah demi mewujudkan otonomi daerah yang sesungguhnya, dan penyelenggaraan pemerintahan yang dinamis (Cahyadi \& Jati, 2016).

Pajak merupakan iuran yang dapat dipaksakan kepada rakyat yang penyelenggaraannya telah diatur oleh undang-undang dan tidak mendapat timbal baliknya secara langsung. Aturan tegas mengenai pajak yang telah ditetapkan dalam undang-undang menjadikan pajak sebagai salah satu jalan strategis untuk melakukan pembangunan yang sesuai dengan kebutuhan masyarakat. Dalam kerangka Negara Indonesia, fungsi perpajakan dilaksanakan oleh Direktorat Jenderal Pajak dibawah naungan Departemen Keuangan Indonesia. Meskipun telah diawasi penuh oleh lembaga resmi pemerintah pusat, namun tetap saja pihak pemerintah daerah harus melakukan pengelolaan pajak secara hati-hati dan tetap bertanggungjawab.

Undang-undang Nomor 28 Tahun 2009 tentang Pajak dan Retribusi daerah telah mengatur mengenai pajak yang diambil dari wajib pajak yang memiliki kendaraan bermotor yang disebut dengan pajak kendaraan bermotor. Pajak semacam ini dapat digunakan pemerintah daerah untuk membiayai pembangunan (Widnyani \& Suardana, 2016). Lembaga yang berwenang dalam mengurus pajak kendaraan bermotor (PKB) ini adalah Badan Pendapatan Daerah melalui Kantor Bersama Sistem Administrasi Manunggal di Bawah Satu Atap (SAMSAT), dimana tugas ini juga dilakukan atas kerjasama dari tiga piha, yaitu Badan Pendapatan Provinsi Bali, Kepolisian RI, dan Asuransi Jasa Raharja. Wajib pajak yang memiliki kendaraan bermotor dengan plat motor wilayah denpasar 
wajib menyelesaikan tugasnya dalam membayar pajak di Kantor Bersama Samsat Denpasar. Berdasarkan data dari Kantor Samsat Denpasar diketahui bahwa jumlah kendaraan bermotor di Kota Denpasar terus mengalami peningkatan selama 4 tahun terakhir dari tahun 2014 sampai tahun 2018, yaitu sebanyak 272.961 sepeda motor di tahun 2014, meningkat menjadi 339.424 di tahun 2018. Peningkatan ini diakibatkan karena meningkatnya tingkat kebutuhan masyarakat terhadap alat transportasi, dan kemampuan beli masyarakat yang cukup tinggi. Selain itu juga dapat disebabkan karena mudahnya persyaratan dalam membeli kendaraan yang banyak ditawarkan oleh show room-show room kendaraan bermotor.

Banyaknya kendaraan bermotor tentunya berimbas pada meningkatnya penerimaan pemerintah yang berasal dari pajak kendaraan bermotor (Widnyani \& Suardana, 2016). Namun hal ini pada kenyataannya masih kurang sesuai karena masih banyaknya wajib pajak yang tidak menunaikan kewajibannya dengan baik sehingga data dari Kantor Samsat Denpasar menunjukkan masih tingginya denda yang terhitung yang dapat dilihat pada tabel 1 .

Tabel 1. Jumlah Objek Kendaraan yang Telah Melaksanakan Kewajiban Perpajakannya, Pokok Penerimaan dan Denda di Kantor Bersama SAMSAT di Kota Denpasar Tahun 2014-2018

\begin{tabular}{llllll}
\hline No. & Tahun & $\begin{array}{l}\text { Jumlah } \\
\text { (Unit) }\end{array}$ & $\begin{array}{l}\text { Pokok } \\
(\mathrm{Rp})\end{array}$ & $\begin{array}{l}\text { Denda } \\
(\mathrm{Rp})\end{array}$ & $\begin{array}{l}\text { Jumlah } \\
(\mathrm{Rp})\end{array}$ \\
\hline 1 & 2014 & 316.503 & 61.725 .819 .211 & 2.013 .705 .611 & 63.628 .413 .711 \\
2 & 2015 & 324.380 & 70.207 .904 .211 & 3.337 .325 .911 & 73.434 .119 .011 \\
3 & 2016 & 328.173 & 75.543 .331 .711 & 4.188 .973 .111 & 79.621 .193 .711 \\
4 & 2017 & 326.109 & 87.041 .519 .311 & 2.639 .061 .756 & 89.569 .469 .956 \\
5 & 2018 & 327.438 & 105.513 .827 .111 & 4.584 .826 .286 & 109.987 .542 .286 \\
\hline
\end{tabular}

Sumber : Data Penelitian, 2018

Berdasarkan tabel 1 dapat diketahui bahwa jumlah denda dari tahun 2014 hingga tahun 2016 meningkat, dan selanjutnya hingga tahun 2018 mengalami fluktuasi namun cenderung meningkat. Tingkat kesadaran wajib pajak akan pentingnya membayar pajak kendaraan bermotor nampaknya masih kurang apabila bercermin dari tabel 1 tersebut.

Perilaku kepatuhan wajib pajak dalam membayar kewajiban pajak mereka adalah penting dalam pengumpulan pajak. Padahal, kondisi ideal tidak selalu terjadi mengingat Wajib Pajak sangat sering berusaha menghindari beban pajak yang dikenakan padanya. Penyebab rendahnya kepatuhan wajib pajak antara lain adalah hasil pemungutan pajak yang tidak langsung dinikmati oleh wajib pajak lainnya, ketidakpuasan publik terhadap layanan publik, pembangunan infrastruktur yang tidak merata, dan jumlah kasus korupsi yang dilakukan oleh pejabat tinggi (Rahmawati \& Yulianto, 2018). Konsep kepatuhan pajak menunjukkan bagaimana wajib pajak mengakomodasi aturan dan peraturan yang berbatasan dengan sistem pajak di suatu negara (Acheampong et al., 2016).

Kepatuhan pajak merupakan salah satu langkah yang tepat untuk mencapai target penerimaan pajak. Semakin patuh wajib pajak maka pendapatan pajak akan semakin meningkat pula (Savitri \& Musfialdy, 2016). Aspek kepatuhan pajak mendorong wajib pajak untuk selalu mematuhi semua aturan 
pajak yang ada, karena merupakan salah satu sumber pendapatan terbesar bagi suatu negara. Namun demikian, sering terjadi penghindaran pajak yang bisa disebabkan oleh kurangnya kepercayaan publik terhadap pengelolaan dana pajak. Wajib Pajak dapat melakukannya dengan sengaja untuk mengurangi jumlah pajak. Apa pun alasannya dari pihak pelaku, penggelapan pajak adalah bentuk perilaku ilegal yang melibatkan dilema etis. Oleh karena itu, peningkatan kepatuhan pajak merupakan masalah penting bagi negara-negara di mana sebagian besar pengeluaran negara didanai oleh pajak, seperti Indonesia (Utami \& Susyanti, 2018). Kepatuhan pajak mengacu pada kesediaan individu untuk bertindak sesuai dengan 'semangat' dan 'surat' hukum dan administrasi pajak tanpa penerapan kegiatan penegakan hukum. kepatuhan pajak sebagai pengajuan semua pengembalian pajak yang diperlukan pada waktu yang tepat dan yang mengembalikan secara akurat melaporkan kewajiban pajak sesuai dengan undang-undang pajak yang berlaku pada saat pengembalian itu diajukan (Saad, 2014).

Kesadaran wajib pajak diartikan sebagai kondisi ketika wajib pajak mengetahui dan melaksanakan kewajiban pajaknya secara tepat dan sukarela (Megawangi \& Setiawan, 2017). Kesadaran wajib pajak sehubungan dengan persepsi wajib pajak menentukan perilaku (keyakinan perilaku yang dirasakan) sesuai dengan pembayaran pajak (Suyanto \& Trisnawati, 2016). Kesadaran diri wajib pajak adalah diperlukan karena sistem penagihan yang berlaku adalah penilaian sendiri yang memberikan peluang penuh bagi wajib pajak untuk menyelesaikan kewajiban pajaknya (Nurkhin et al., 2018). Kesadaran atau awarena adalah elemen manusia dalam memahami realitas dan bagaimana bereaksi atau merespons realitas. Kesadaran bahwa manusia mencakup kesadaran diri, sesama, masa lalu, dan kemungkinan masa depan mereka. Kesadaran masyarakat akan perpajakan berarti bahwa wajib pajak ingin membayar pajak karena mereka tidak dirugikan dalam pengumpulan pajak dilakukan dan tidak merasakan paksaan. Namun, kesadaran pajak seringkali menjadi kendala atau masalah untuk mengumpulkan pajak dari masyarakat. Banyak orang yang tidak tahu bentuk konkret kompensasi untuk pajak yang telah mereka bayar (Nurlis \& Kamil, 2015).

Kepatuhan Wajib Pajak juga dipengaruhi oleh kesadaran wajib pajak. Kesadaran diri wajib pajak diperlukan karena sistem penagihan yang berlaku adalah penilaian diri yang memberikan kesempatan penuh bagi wajib pajak untuk menyelesaikan kewajiban pajaknya. Wajib pajak dengan kesadarannya harus membayar pajak dengan benar (semua pendapatan sudah dilaporkan). Namun pada kenyataannya, semua orang cenderung menghindari membayar pajak (Nurkhin et al., 2018). Beberapa penelitian yang berfokus pada kesadaran wajib pajak pada kepatuhan pajak memperoleh hasil serupa yakni pengaruh positif kesadaran wajib pajak pada kepatuhan wajib pajak, diantaranya penelitian (Suriambawa \& Setiawan, 2018), (Susilawati \& Budiartha, 2013), (Putri \& Jati, 2013), (Tiraada, 2013), dan (Dewi \& Setiawan, 2016).

Adanya sanksi yang mengatur secara tegas terkait pembayaran pajak cenderung dapat meningatkan kepatuhan wajib pajak dalam membayar kewajibannya. Sanksi Perpajakan adalah jaminan atau upaya preventif (preventif) sehingga peraturan perpajakan yang telah diatur dapat dipatuhi dan 
tidak dilanggar oleh wajib pajak, yang taat membayar pajak serta memberikan efek jera bagi pelanggar (Nurlaela, 2018). Pengenaan sanksi pajak yang diberlakukan untuk menciptakan kepatuhan dalam melaksanakan kewajiban pajaknya. Karena itu, penting bagi wajib pajak untuk memahami sanksi pajak untuk mengetahui konsekuensi hukum dari apa yang dilakukan atau tidak dilakukan. Sanksi diperlukan untuk memberikan pelajaran bagi para pelanggar pajak. Dengan demikian, diharapkan peraturan pajak dipatuhi oleh wajib pajak (Purnamasari \& Sudaryo, 2018).

Penelitian terkait pengaruh sanksi pajak pada kepatuhan wajib pajak memperoleh hasil yang berbeda. Penelitian oleh Suriambawa \& Setiawan (2018), Utama (2013), Putri \& Jati (2013), Pratiwi \& Setiawan (2014) memberikan hasil bahwa sanksi pajak dapat meningkatkan kepatuhan wajib pajak dalam membayar pajak. Namun hasil ini tidak sejalan dengan hasil penelitian Widawati (2017) dan Winerungan (2013) dimana pada penelitian tersebut sanksi pajak tidak mampu meningkatkan kepatuhan wajib pajak, sebab kesadaran wajib pajak yang masih minim sehingga sanksi tidak dapat menjadi alasan wajib pajak untuk patuh pada kewajibannya.

Upaya lain yang dapat dilakukan untuk meningkatkan kepatuhan wajib pajak adalah dengan memberikan pelayanan yang memuaskan kepada wajib pajak. Pelayanan dalam hal ini dapat berupa kualitas sumber daya manusia sebagai petugas perpajakan, peningkatan kualitas sarana dan prasarana perpajakan, serta pemanfaatan teknologi canggih untuk mempermudah wajib pajak (Mahardika, 2015). Fiskus yang mampu memberikan pelayanan yang baik, ramah, dan menjelaskan kemudahan proses pembayaran pajak serta pentingnya membayar pajak, dan tak lupa pula sanksi yang dapat diperolah apabila tidak menyelesaikan kewajiban pajak dapat membuat wajib pajak sadar dan mengerti akan pentingnya membayar pajak, sehingga meningkatkan kepatuhan pajaknya. Komala dkk. (2014), Juventia (2014), dan Cahyadi \& Jati (2016) menemukan hasil penelitian terkait kualitas pelayanan fiskus yang meningkatkan kepatuhan pajak. Namun, hal ini tidak sejalan dengan hasil penelitian Ester dkk. (2017) yang memperoleh hasil bahwa kualitas pelayanan tidak dapat membuat wajib pajak mematuhi kewajibannya.

Teori perilaku terencana menjelaskan bahwa perilaku yang dihasilkan oleh individu timbul karena adanya niat untuk berperilaku (Nurlis \& Kamil, 2015). Sedangkan kemunculan niat untuk berperilaku ditentukan oleh tiga faktor menurut Ajzen, (1991) yaitu behavioral beliefs, keyakinan individu adalah hasil dari perilaku dan evaluasi hasil, keyakinan normatif, yaitu keyakinan tentang harapan normatif orang lain dan motivasi untuk memenuhi harapan ini dan control beliefs, adalah keyakinan akan adanya hal-hal yang mendukung atau menghambat perilaku yang akan ditampilkan dan persepsi seberapa kuat hal-hal yang mendukung dan menghambat perilaku (daya yang dirasakan). Niat pada gilirannya ditentukan oleh sikap terhadap perilaku, faktor pribadi, dan faktor sosial, norma subyektif, tekanan sosial yang dirasakan dari rujukan signifikan untuk melakukan perilaku dan motivasi aktor untuk mematuhi rujukan.

Sikap dan norma subyektif pada gilirannya ditentukan oleh keyakinan menonjol yang dipegang orang tentang perilaku tersebut. Sikap dirumuskan oleh keyakinan tentang hasil dari melakukan perilaku apa pun dan kepentingan yang 
dirasakan dari hasil itu untuk aktor. Jadi, sikap terhadap perilaku apa pun adalah fungsi dari kekuatan yang akan dihasilkan oleh perilaku itu hasil dan evaluasi hasil itu. Dalam cara yang serupa, norma subyektif bergantung pada pandangan orang lain yang penting, dalam kehidupan orang lain, dan motivasi mereka untuk mematuhinya (Kiriakidis, 2015). Ketika akan melakukan sesuatu, orang akan memiliki kepercayaan diri tentang harapan normatif orang lain dan motivasi untuk memenuhi harapan tersebut (kepercayaan normatif). Jika pernyataan ini dikaitkan dengan pajak, bahwa adanya kepuasan layanan otoritas pajak, sistem pajak yang efisien dan efektif, dan konseling pajak untuk memotivasi wajib pajak untuk mematuhi pajak akan mendorong setiap wajib pajak memiliki kepercayaan diri dan memutuskan untuk menjadi patuh wajib pajak membayar kewajiban pajak. Denda pajak terkait dengan keyakinan kontrol. Denda pajak dirancang sedemikian rupa untuk mendorong wajib pajak patuh pada aturan pajak yang berlaku. Tingkat kepatuhan wajib pajak akan ditentukan berdasarkan persepsi wajib pajak tentang seberapa kuat sanksi pajak untuk mendukung kepatuhan wajib pajak (Nurlis \& Kamil, 2015).

Teori pembelajaran sosial menyatakan bahwa seseorang dapat belajar dari pengalaman dan pengamatan yang langsung dilakukannya. Teori ini didasarkan pada gagasan bahwa kita belajar dari interaksi kita dengan orang lain dalam konteks sosial. Secara terpisah, dengan mengamati perilaku orang lain, orang mengembangkan perilaku serupa. Setelah mengamati perilaku orang lain, orang mengasimilasi dan meniru perilaku itu, terutama jika pengalaman pengamatan mereka positif atau termasuk imbalan yang terkait dengan perilaku yang diamati (Nabavi, 2016). Jenis pembelajaran melibatkan empat tahap yang berbeda- perhatian, retensi, reproduksi dan motivasi. Tahap pertama adalah perhatian dimana peserta didik perlu memperhatikan perilaku tersebut. Mereka perlu benar-benar melihat perilaku yang ingin mereka reproduksi atau yang orang lain inginkan mereka untuk mereproduksi. Kedua, mereka perlu menginternalisasi dan mempertahankan apa yang telah mereka lihat. Ini melibatkan proses kognitif di mana pelajar secara mental melatih perilaku atau tindakan yang harus direproduksi. Yang ketiga mereka butuhkan kesempatan untuk mereproduksi perilaku dengan mengonversi informasi yang diperoleh dari proses perhatian dan retensi menjadi tindakan. Akhirnya peserta didik perlu termotivasi menerapkan atau meniru perilaku yang telah mereka amati (Bandura, 1978).

Pajak merupakan pungutan wajib pemerintah pusat maupun daerah kepada masyarakat, dan memiliki aturan resmi yang memaksakan pungutan tersebut. Pajak kendaraan bermotor adalah pajak atas kepemilikan kendaraan bermotor bagi masyarakat sebagai sumber dari pendapatan pemerintah daerah. Pasal 10 UU No. 16 Tahun 2000 tentang Ketentuan dan Tata Cara Perpajakan menyebutkan persyaratan dalam pemungutan pajak kendaraan bermotor yakni wajib pajak perlu membawa beberapa perlengkapan seperti, Surat Tanda Nomor Kendaraan (STNK) asli, Buku Pemilik Kendaraan Bermotor (BPKB) asli, Kartu Tanda Penduduk sesuai dengan yang tertera pada STNK, Bukti Pelunasan PKB dan Surat Ketetapan Pajak Daerah tahun terakhir yang telah divalidasi.

Kesadaran adalah elemen dalam manusia untuk memahami realitas dan bagaimana mereka bertindak atau berperilaku terhadap realitas. Kesadaran 
merupakan bentuk partisipasi dalam mendukung pembangunan negara. Mengetahui hal ini, wajib pajak ingin membayar pajak karena mereka tidak dirugikan dari pemungutan pajak. Kesadaran yang nyata menunda pembayaran pajak dan mengurangi beban pajak sangat merugikan negara. Dalam hal ini, wajib pajak ingin membayar pajak karena mereka mengerti bahwa keterlambatan pembayaran pajak dan pengurangan dampak beban pajak pada kurangnya sumber daya keuangan, yang dapat menyebabkan keterlambatan dalam pembangunan negara. Kesadaran mendefinisikan bahwa pajak ditetapkan oleh hukum dan dapat ditegakkan. Wajib Pajak akan membayar untuk pembayaran pajak telah menyadari dasar hukum yang kuat dan merupakan kewajiban mutlak setiap warga negara (Wijaya, 2019).

Teori perilaku terencana menyatakan bahwa perilaku seseorang dilaksanakan apabila terdapat niat dari dalam diri orang tersebut untuk melakukannya. Apabila wajib pajak memiliki niat untuk melakukan kewajban pajaknya, dan sadar akan pentingnya kepatuhan tersebut maka wajib pajak akan melakukan pembayaran pajaknya dengan teratur. Penelitian terkait kesadaran wajib pajak pada kepatuhan pajak yang dilakukan oleh Tiraada (2013), Pratiwi \& Setiawan (2014), serta Dewi \& Setiawan (2016) memperoleh hasil yang sama yakni kesadaran yang tinggi dari wajib pajak akan pentingnya pembayaran pajak guna pembangunan negara dapat meningkatkan kepatuhan dalam pembayaran pajak. Berdasarkan hal tersebut, maka hipotesis pertama dalam penelitian ini adalah.

$\mathrm{H}_{1}$ : Kesadaran wajib pajak berpengaruh positif terhadap kepatuhan wajib pajak kendaraan bermotor di Kantor Bersama Samsat di Kota Denpasar.

Berhasil atau tidaknya pemungutan pajak dipengaruhi oleh ketentuan pajak (tax policy), adminstrasi pajak (tax administration), dan hukum pajak (tax law). Ketiga hal penting tersebut dijalankan oleh fiskus. Oleh karena itulah mengapa pelayanan yang diberikan fiskus menjadi sangat penting. Fiskus hendaknya daapat menjelaskan dengan baik dan benar mengenai ketentuan pajak, melakukan administrasi pajak dengan tepat, dan berani menegakkan hukum pajak apabila ada yang terbukti melanggar.

Sistem perpajakan yang kini menjadi Self-Assesment System memaksa wajib pajak untuk menghitung, melaporkan, dan membayar kewajiban pajaknya. Sistem ini menuntuk kepatuhan yang tinggi dari wajib pajak untuk membayar pajaknya kepada negara. Fiskus yang memberikan pelayanan terbaik, menjelaskan dengan benar mekanisme dan tata cara perpajakan kepada wajib pajak tentu dapat menignkatkan kepatuhan pajak. Hal ini sejalan dengan penelitian Pratiwi \& Setiawan (2014), Widnyani \& Suardana (2016), Komala dkk. (2014) dan Juventia, (2014) yang memperoleh hasil bahwa fiskus yang memberikan pelayanan yang baik dapat membuat patuh wajib pajak. Berdasarkan hal tersebut, hipotesis kedua dalam penelitian ini yaitu.

$\mathrm{H}_{2}$ : Pelayanan fiskus berpengaruh positif terhadap kepatuhan wajib pajak kendaraan bermotor di Kantor Bersama Samsat di Kota Denpasar.

Sanksi pajak merupakan tindakan hukum yang diberikan kepada wajib pajak yang melakukan pelanggaran terhadap peraturan perpajakan yang berlaku, dalam bukunya Mardiasmo (2013) menyebutkan dua jenis sanksi, yakni sanki administrasi yaitu pembayaran kerugian negara berupa denda atau bunga 
lainnya, dan sanksi pidana merupakan jalan terakhir yang diambil fisku untuk tetap menegakkan peraturan perpajakan. Sanksi admnistrasi terdiri atas tiga jnais menurut Ilyas \& Burton (2013) diantaranya sanksi administrasi berupa denda, bunga, dan kenaikan. Sedangkan sanksi pidana menurut Mardiasmo (2013) terdiri atas sanksi pidana berupa denda pidana, pidana kurungan, dan pidana penjara.

Dalam teori pembelajaran sosial, wajib pajak dapat belajar dengan mengamati wajib pajak lainnya dan mengalami sanksi langsung yang dikenakan oleh otoritas pajak kepada wajib pajak jika melanggar norma perpajakan. Pengamatan dan pengalaman langsung ini menjadi dasar bagi Wajib Pajak untuk menilai sanksi dan memilih untuk berperilaku sesuai atau tidak. Dengan demikian, semakin tegas sanksi pajak, semakin tinggi wajib pajak akan berperilaku patuh. Pratiwi \& Setiawan (2014), Dewi \& Setiawan (2016), serta Cahyadi \& Jati (2016) memperoleh hasil penelitian bahwa sanksi pajak memberikan pengaruh positif pada kepatuhan pajak. Berdasarkan hal tersebut, hipotesis ketiga dalam penelitian ini dirumuskan sebagai berikut.

$\mathrm{H}_{3}$ : Sanksi Pajak berpengaruh positif terhadap Kepatuhan Wajib Pajak Kendaraan Bermotor di Kantor Bersama Samsat di Kota Denpasar.

\section{METODE PENELITIAN}

Penelitian ini merumuskan bagaimana pengaruh yang diberikan kesadaran wajib pajak, pelayanan fisku, dan sanksi pajak pada kepatuhan perpajakan. Penelitian bersifat asosiatif kuantitatif untuk menguji populasi dan sampel tertentu untuk menguji hipotesis. Kerangka konsep penelitian dapat dilihat berikut ini.

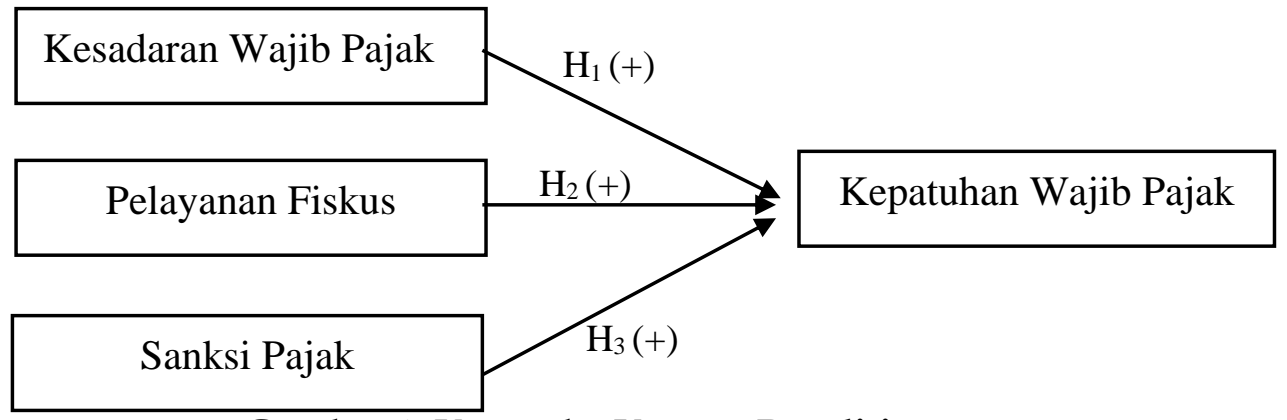

\section{Gambar 1. Kerangka Konsep Penelitian}

Sumber: Data Penelitian, 2018

Penelitian ini dilakukan di Kantor Samsat Bersama Kota Denpasar dimana populasinya adalah seluruh wajib pajak kendaraan bermotor yang terdaftar di Kantor Samsat Kota Denpasar yang berjumlah 393.598 unit kendaraan bermotor. Sampel dikumpulkan dengan metode purposive sampling dengan kriteria yaitu seluruh wajib pajak kendaraan bermotor yang terdaftar di Kantor Samsat Kota Denpasar, pemilik kendaraan plat hitam dan kendaraan motornya merupakan milik pribadi. Menentukan jumlah sampel yang akan digunakan, peneliti menggunakan rumus slovin berikut ini.

$n=\frac{N}{\left(1+N e^{2}\right)}$

Keterangan:

$\mathrm{n} \quad=$ jumlah anggota sampel

46 
$\mathrm{N} \quad=$ jumlah anggota populasi

$\mathrm{e} \quad=$ nilai kritis (batas ketelitian 0,10 )

Berdasarkan rumus tersebut, maka perhitungan sampel dalam penelitian ini adalah sebagai berikut :

$n=\frac{393.598}{\left(1+393.598(0,10)^{2}\right)}$

$\mathrm{n}=99,97$ dibulatkan 100

Maka dari itu, jumlah sampel yang digunakan adalah sebanyak 100 responden.

Pengumpulan data dilakukan dengan metode observasi dan wawancara, serta memberikan kuesioner dengan menggunakan skala likert 1-5 poin. Teknik analisis data menggunakan regresi linear berganda, dengan rumus berikut.

$Y=\alpha+\beta_{1} X_{1}+\beta_{2} X_{2}+\beta_{3} X_{3}+e$

Keterangan:

Y : Environmental Disclosure (ED) (skor GRI)

a $\quad$ : Nilai Konstanta

$\beta_{1-} \beta_{3} \quad:$ Koefisien regresi

$\mathrm{X}_{1} \quad$ : Kesadaran Wajib Pajak

$\mathrm{X}_{2} \quad$ : Pelayanan Fiskus

$\mathrm{X}_{3} \quad$ : Sanksi Perpajakan

$\varepsilon_{1} \quad$ : variabel pengganggu

\section{HASIL DAN PEMBAHASAN}

Penelitian ini dilakukan di Kantor Samsat Kota Denpasar dengan populasi yaitu seluruh wajib pajak kendaraan bermotor Kota Denpasar. Pengumpulan data dilakukan dengan menyebarkan 100 kuesioner kepada wajib pajak yang sesuai kriteria. Namun sebelum itu, peneliti melakukan wawancara singkat kepada wajib pajak untuk memastikan bahwa wajib pajak merupakan pemilik kendaraan bermotor plat hitam. Penelitian dilakukan selama satu minggu. Distribusi kuesioner beserta tingkat pengembalian kuesioner yang dapat diolah disajikan dalam tabel 2. sebagai berikut.

Tabel 2. Rincian Pengiriman dan Pengembalian Kuesioner

\begin{tabular}{ll}
\hline Keterangan & Jumlah \\
\hline Kuesioner yang disebar & 100 \\
Kuesioner yang tidak kembali & - \\
Kuesioner yang dikembalikan & 100 \\
$\begin{array}{l}\text { Kuesioner yang digunakan } \\
\text { Tingkat Pengembalian (Respons rate) }\end{array}$ & 100 \\
$\begin{array}{l}\text { Kuesioner yang dikembalikan } \times 100 \% \\
\text { Kuesioner yang dikirim }\end{array}$ & $100 \%$ \\
$\begin{array}{l}\text { Tingkat Pengembalian yang digunakan (useable response rate) } \\
\text { Kuesioner yang diolah } \times 100 \%\end{array}$ & $100 \%$ \\
\hline Kuesioner yang dikirm & \\
\hline
\end{tabular}

Sumber : Data Penelitian, 2018

Sesuai tabel 2 maka kuesioner yang disebarkan sebanyak 100 kuesioner dan yang kembali adalah 100 kuesioner sehingga peneliti menggunakan 100 kuesioner dalam penelitian ini.

Kuesioner sebelum digunakan terlebih dahulu harus diuji validitas dan reliabilitasnya. Pengujian ini bertujuan untuk menentukan apakah kuesioner 
layak untuk digunakan dalam meneliti yang hendak diteliti oleh penulis. Jika seluruh pertanyaan dalam kuesioner dikatakan valid dan reliabel, hal ini menunjukkan bahwa kuesioner tepat dan layak untuk digunakan dalam penelitian. Data valid adalah data yang mampu mengukur yang seharusnya diukur dengan nilai di atas 0,30. Berikut hasil validitas data pada tabel 3.

Tabel 3. Rekapitulasi Hasil Uji Validitas Instrumen Penelitian

\begin{tabular}{lllll}
\hline Variabel & Indikator & $\begin{array}{l}\text { Koefisien } \\
\text { Korelasi }\end{array}$ & $\begin{array}{l}\text { Sig. } \\
\text { tailed })\end{array}$ & $\begin{array}{c}\text { (2- } \\
\text { Keterangan }\end{array}$ \\
\hline & $\mathrm{X}_{1.1}$ & 0,838 & 0,000 & Valid \\
Kesadaran & $\mathrm{X}_{1.2}$ & 0,837 & 0,000 & Valid \\
Wajib Pajak $\left(\mathrm{X}_{1}\right)$ & $\mathrm{X}_{1.3}$ & 0,810 & 0,000 & Valid \\
& $\mathrm{X}_{1.4}$ & 0,814 & 0,000 & Valid \\
& $\mathrm{X}_{1.5}$ & 0,846 & 0,000 & Valid \\
& $\mathrm{X}_{1.6}$ & 0,702 & 0,000 & Valid \\
& $\mathrm{X}_{2.1}$ & 0,820 & 0,000 & Valid \\
& $\mathrm{X}_{2.2}$ & 0,8250 & 0,000 & Valid \\
& $\mathrm{X}_{2.3}$ & 0,745 & 0,000 & Valid \\
& $\mathrm{X}_{2.4}$ & 0,766 & 0,000 & Valid \\
& $\mathrm{X}_{2.5}$ & 0,706 & 0,000 & Valid \\
& $\mathrm{X}_{2.6}$ & 0,642 & 0,000 & Valid \\
& $\mathrm{X}_{3.1}$ & 0,768 & 0,000 & Valid \\
& $\mathrm{X}_{3.2}$ & 0,755 & 0,000 & Valid \\
& $\mathrm{X}_{3.3}$ & 0,731 & 0,000 & Valid \\
& $\mathrm{X}_{3.4}$ & 0,743 & 0,000 & Valid \\
& $\mathrm{X}_{3.5}$ & 0,808 & 0,000 & Valid \\
& $\mathrm{X}_{3.6}$ & 0,687 & 0,000 & Valid \\
& $\mathrm{Y}_{1}$ & 0,768 & 0,000 & Valid \\
& $\mathrm{Y}_{2}$ & 0,765 & 0,000 & Valid \\
& $\mathrm{Y}_{3}$ & 0,755 & 0,000 & Valid \\
& $\mathrm{Y}_{4}$ & 0,755 & 0,000 & Valid \\
& $\mathrm{Y}_{5}$ & 0,782 & Valid \\
& $\mathrm{Y}_{6}$ & 0,729 & Valid \\
\hline
\end{tabular}

Sumber : Data Penelitian, 2018

Uji reliabilitas menggunakan nilai Alpha Cronbach dengan nilai di atas 0,60, dimana uji ini digunakan untuk mengetahui unidimensionalitas butir-butir pernyataan terhadap variabel laten yang diteliti (kesadaran wajib pajak, pelayanan fiskus, sanksi perpajakan dan kepatuhan wajib pajak). Rekapitulasi hasil uji reliabilitas instrumen penelitian dapat dilihat pada tabel 4 . berikut.

Tabel 4. Rekapitulasi Hasil Uji Reliabilitas Instrumen Penelitian

\begin{tabular}{llll}
\hline No. & Variabel & Cronbach's Alpha & Keterangan \\
\hline 1 & Kesadaran Wajib Pajak $\left(\mathrm{X}_{1}\right)$ & 0,800 & Reliabel \\
2 & Pelayanan fiskus $\left(\mathrm{X}_{2}\right)$ & 0,789 & Reliabel \\
3 & Sanksi Perpajakan $\left(\mathrm{X}_{3}\right)$ & 0,788 & Reliabel \\
4 & Kepatuhan Wajib Pajak $(\mathrm{Y})$ & 0,791 & Reliabel \\
\hline Sumber $:$ Data Penelitian, 2018 & &
\end{tabular}

Sumber: Data Penelitian, 2018 
Penyajian tabel 4 memperlihatkan bahwa instrumen penelitian reliabel dan layak untuk digunakan dalam penelitian dan telah teruji keandalannya karena nilai Cronbach's Alpha di atas 0,60.

Untuk mendeskripsikan penilaian rata-rata responden mengenai variabel-variabel dalam penelitian, hasil jawaban responden disesuaikan dengan desain skala pengukuran yang telah ditetapkan kemudian diformulasikan ke dalam beberapa interval kelas. Rumus interval kelas adalah sebagai berikut.

Interval kelas $=\frac{\text { Nilai tertinggi }- \text { nilai terendah }}{\text { Jumlah kelas }}$

Interval kelas $=\frac{5-1}{5}=0,80$

Dari interval kelas tersebut maka dapat diketahui batasan nilai masingmasing kelas menjadi dasar penentu katagori rata-rata jawaban responden penelitian.

$$
\begin{array}{ll}
1,00-1,79 & =\text { Sangat tidak baik } \\
1,80-2.59 & =\text { Tidak baik } \\
2,60-3,39 & =\text { Kurang Baik } \\
3,40-4,19 & =\text { Baik } \\
4,20-5,00 & =\text { Sangat baik }
\end{array}
$$

Berdasarkan hasil interval range maka dapat disusun kriteria untuk masing-masing variabel dalam Tabel 5 . berikut.

Tabel 5. Rangkuman Rata-Rata Skor Variabel Penelitian

\begin{tabular}{lcc}
\hline Variabel & Rata-Rata & Keterangan \\
\hline Kesadaran Wajib Pajak & 3,90 & Tinggi \\
Pelayanan Fiskus & 3,93 & Tinggi \\
Sanksi Pajak & 4,07 & Tinggi \\
Kepatuhan Wajib Pajak & 4,00 & Tinggi \\
\hline
\end{tabular}

Sumber : Data Penelitian, 2018

Tabel 5 menunjukkan bahwa keempat variabel penelitian memiliki ratarata jawaban responden yang tinggi. semakin tinggi nilai rata-rata yang diperoleh menunjukkan semakin baik tanggapan responden terhadap item maupun variabel tersebut.

Model regresi akan lebih tepat digunakan dan menghasilkan perhitungan yang lebih akurat, apabila beberapa asumsi berikut dapat terpenuhi. Uji asumsi klasik yang harus dipenuhi pada analisis regresi linear sederhana antara lain Uji Normalitas, Uji Multikolenearitas dan Uji Heterokedastisitas. Uji normalitas dikatakan terpenuhi apabila nilai signifikan di atas 0,05 dengan uji KolmogorovSmirnov, yang bisa dilihat pada tabel 6 .

Tabel 6. Hasil Uji Normalitas

\begin{tabular}{ll}
\hline & Unstandardized Residual \\
\hline $\mathrm{N}$ & 100 \\
Kolmogorov-Smirnov Z & 1,048 \\
Asymp.Sig.(2-tailed) & 0,222 \\
\hline
\end{tabular}

Sumber : Data Penelitian, 2018 
Dari tabel 6 di atas dapat disimpulkan bahwa model regresi lolos uji normalitas karena nilai signifikansi 0,222 di atas 0,05, maka dapat disimpulkan bahwa model regresi berdistribusi normal.

Model regesi yang layak digunakan dalam penelitian tidak memiliki korelasi antar variabel bebasnya yang dapat dilihat pada uji multikoliniearitas, dengan nilai tolerance di atas 0,1 dan VIF kurang dari 10, seperti yang ditunjukkan pada tabel 7 berikut ini.

Tabel 7. Hasil Uji Multikoleniaritas

\begin{tabular}{llll}
\hline Variabel & Tolerance & VIF & Keterangan \\
\hline Kesadaran Wajib Pajak $\left(\mathrm{X}_{1}\right)$ & 0,490 & 2,042 & Bebas multikolinieritas \\
Pelayanan fiskus $\left(\mathrm{X}_{2}\right)$ & 0,436 & 2,294 & Bebas multikolinieritas \\
Sanksi Perpajakan $\left(\mathrm{X}_{3}\right)$ & 0,593 & 1,686 & Bebas multikolinieritas \\
\hline
\end{tabular}

Sumber : Data Penelitian, 2018

Tabel 7 menunjukkan nilai tolerance semua variabel bebas lebih dari 0,1 dan VIF kurang dari 10, sehingga dapat disimpulkan bahwa model regresi tidak menganduk korelasi tiap variabel dan layak digunakan dalam penelitian.

Uji heteroskedastisitas digunakan untuk menguji apakah dalam model regresi mengandung ketidaksamaan varian, dimana model yang baik seharusnya memiliki varians yang homogen. Untuk memenuhi uji ini, nilai signifikansi variabel harus lebih dari 0,05 melalui uji Glejser, yang dapat dilihat pada tabel 8 .

Tabel 8. Hasil Uji Heteroskedastisitas

\begin{tabular}{lll}
\hline \multicolumn{1}{c}{ Variabel } & Signifikansi & Keterangan \\
\hline Kesadaran Wajib Pajak $\left(\mathrm{X}_{1}\right)$ & 0,844 & Bebas Heteroskedastisitas \\
Pelayanan fiskus $\left(\mathrm{X}_{2}\right)$ & 0,054 & Bebas Heteroskedastisitas \\
Sanksi Perpajakan $\left(\mathrm{X}_{3}\right)$ & 0,733 & Bebas Heteroskedastisitas \\
\hline
\end{tabular}

Sumber : Data Penelitian, 2018

Hasil uji pada tabel 8 memperlihatkan bahwa semua variabel memiliki gejala yang homogen karena nilai signifikansi lebih dari 0,05, sehingga model regresi layak untuk digunakan dalam penelitian ini.

Setelah semua asumsi klasik terpenuhi, maka selanjutnya memaparkan hasil analisis regresi linier berganda. Analisis regresi linear berganda ini bertujuan untuk menentukan bagaimana pengaruh dari variabel bebas kesadaran wajib pajak, pelayanan fiskus dan sanksi perpajakan pada variabel terikatnya yaitu kepatuhan wajib pajak kendaraan bermotor, apakah berpengaruh positif ataupun negatif, dan bagaimana pengaruh tersebut signifikan ataupun tidak signifikan. Perhitungan koefisien regresi linier berganda dilakukan dengan analisis regresi melalui software SPSS 18.0 for Windows, diperoleh hasil yang ditunjukan pada tabel 9.

Berdasarkan hasil analisis regresi linier berganda seperti yang disajikan pada Tabel 9, maka dapat dibuat persamaan regresi sebagai berikut:

$$
\mathrm{Y}=2,078+0,160 \mathrm{X}_{1}+0,382 \mathrm{X}_{2}+0,376 \mathrm{X}_{3}
$$

Nilai koefisien regresi masing-masing variabel bebas bernilai positif dengan nilai signifikansi uji t kurang dari 0,05. Hal ini menunjukkan bahwa semua variabel bebas memiliki pengaruh positif yang signifikan terhadap variabel terikat.

Koefisien determinasi digunakan untuk menilai seberapa besar variabel bebas dapat mempengaruhi variabel terikat yang dilihat dari nilai $R$ Square. Pada tabel 9 dapat dilihat bahwa nilai $R$ Square sebesar 0,662 ini menunjukkan bahwa 
sebesar $66,2 \%$ kepatuhan wajib pajak dipengaruhi oleh kesadaran wajib pajak, pelayanan fiskus, dan sanksi pajak. Dan sisanya sebesar 33,8\% dipengaruhi oleh variabel lain yang tidak termasuk dalam model penelitian.

\section{Tabel 9. Hasil Analisis Regresi Linier Berganda}

\begin{tabular}{llllll}
\hline \multirow{2}{*}{ Model } & \multicolumn{2}{l}{$\begin{array}{l}\text { Unstandardized } \\
\text { Coefficients }\end{array}$} & \multicolumn{2}{l}{$\begin{array}{l}\text { Standardized } \\
\text { Coefficients }\end{array}$} & \\
\cline { 2 - 5 } & $\mathrm{B}$ & Std. Error & Beta & $\mathrm{t}$ & Sig. \\
\hline 1 (Constant) & 2,078 & 1,655 & & 1,256 & 0,212 \\
Kesadaran Wajib Pajak & 0,160 & 0,073 & 0,186 & 2,198 & 0,030 \\
Pelayanan Fiskus & 0,382 & 0,086 & 0,399 & 4,442 & 0,000 \\
Sanksi Perpajakan & 0,376 & 0,083 & 0,349 & 4,525 & 0,000 \\
$R$ Square & & & 0,662 & & \\
F hitung & & & 62,713 & & \\
Signifikansi F & & 0,000 & & \\
\hline
\end{tabular}

Sumber : Data Penelitian, 2018

Uji kelayakan model regresi bertujuan untuk mengetahui apakah semua variabel bebas yang diidentifikasi (kesadaran wajib pajak, pelayanan fiskus, dan sanksi perpajakan) tepat digunakan memprediksi kepatuhan wajib pajak. Tabel 9 memperlihatkan bahwa nilai signifikansi $\mathrm{F}$ adalah sebear 0,000 kurang dari 0,05. Hasil ini mempunyai arti bahwa ada pengaruh signifikan antara faktor kesadaran wajib pajak, pelayanan fiskus, dan sanksi perpajakan secara simultan terhadap kepatuhan wajib pajak.

Hasil uji $\mathrm{t}$ untuk variabel pertama yakni kesadaran wajib pajak menunjukkan nilai signifikansi ukuran perusahaan yaitu 0,030 yang mana nilai tersebut $<0,05$ yang berarti $\mathrm{H}_{1}$ diterima (koefisien regresi signifikan). Hal ini menunjukkan bahwa hipotesis pertama diterima yaitu kesadaran wajib pajak berpengaruh positif pada kepatuhan wajib pajak. Kesadaran wajib pajak dalam membayar pajak tepat waktu akan mempengaruhi tinggi dan rendahnya kepatuhan pajak. Kesadaran adalah kondisi tahu, memahami keadaan dan merasakan. Oleh karena itu, melakukan kewaspadaan perpajakan adalah memahami sikap wajib pajak atau wajib pajak orang pribadi untuk memahami makna, fungsi dan tujuan pembayaran pajak (Wicaksono \& Lestari, 2017).

Teori perilaku terencana menunjukkan bahwa individu akan melakukan tindakan atau perilaku berdasarkan atas niat yang berasal dari dalam dirinya sendiri. Niat ini sama halnya dengan kesadaran yang tumbuh dari dalam diri sendiri untuk melakukan suatu tindakan atau perilaku. Wajib pajak yang memiliki niat untuk membayar pajak berarti wajib pajak tersebut sadar bahwa dengan membayar pajak dapat membantu pemerintah memberikan kehidupan yang lebih sejahtera kepada masyarakat sehingga mendorong dirinya untuk melakukan kewajibannya dengan patuh. Hasil penelitian ini mendukung penelitian (Suriambawa \& Setiawan, 2018), (Susilawati \& Budiartha, 2013), (Putri \& Jati, 2013), (Tiraada, 2013), serta (Dewi \& Setiawan, 2016).

Hasil uji $\mathrm{t}$ variabel kedua yakni pelayanan fiskus menunjukkan nilai signifikansi 0,000 yang mana nilai tersebut $<0,05$ yang berarti $\mathrm{H}_{2}$ diterima (koefisien regresi signifikan). Sehingga dapat disimpulkan bahwa pelayanan fiskus berpengaruh positif pada kepatuhan wajib pajak. Pelayanan petugas kepada wajib pajak dapat mempengaruhi patuh atau tidaknya wajib pajak dalam membayar pajak (Jatmiko, 2006). Sistem dan mekanismen pembayaran pajak 
yang sering mengalami perubahan dapat menimbulkan kebingungan bagi wajib pajak sehingga disinilah tugas fiskus untuk memberikan pengetahuan mengenai perpajakan, baik berupa ketentuan pajak, sanksi pajak, dan peraturan pajak sehingga wajib pajak paham mengenai pentingnya patuh pada pembayaran pajak.

Teori pembelajaran sosial mengemukakan bahwa seseorang akan belajar dari apa yang mereka lihat, dan dengar dari orang lain. Hal ini mengindikasikan bahwa apabila fiskus mampu memberikan pengetahuan dan wawasan mengenai hal-hal yang berkaitan dengan kewajiban pajak bagi wajib pajak, maka wajib pajak akan belajar dari hal tersebut dan mulai patuh terhadap pembayaran pajak, Temuan penelitian ini juga mendukung hasil temuan Komala dkk. (2014), Juventia (2014), Pratiwi \& Setiawan (2014), Widnyani \& Suardana (2016), serta Cahyadi \& Jati (2016) yang memperoleh hasil serupa yaitu kualitas pelayanan fiskus meningkatkan kepatuhan wajib pajak dalam membayar kewajiban pajaknya.

Hasil uji $\mathrm{t}$ pada variabel ketiga yaitu sanksi pajak diperoleh nilai signifikansi 0,000 yang mana nilai tersebut $<0,05$ yang berarti $\mathrm{H}_{3}$ diterima (koefisien regresi signifikan). Hal ini mengandung arti bahwa sanksi pajak memiliki pengaruh positif pada kepatuhan wajib pajak. Penerapan sanksi pajak sebenarnya bertujuan untuk menuntuk wajib pajak mematuhi peraturan dan membayar kewajiban pajak tepat pada waktunya. Sanksi ini diterapkan dengan harapan bahwa wajib pajak akan tertib dalam membayar pajak.

Teori pembelajaran sosial berpendapat bahwa individu yang melihat dan mendengar sesuatu dari orang lain akan menjadikan hal tersebut sebagai pelajaran terhadap dirinya sendiri. Pengetahuan akan sanksi pajak yang dapat diterima apabila melanggar kewajiban dapat menjadi pelajaran sosial bagi individu wajib pajak untuk patuh pada kewajiban pajaknya karena ketidakpatuhan dapat memberikan sanksi yang merugikan wajib pajak. Temuan penelitian ini juga didukung oleh Suriambawa \& Setiawan (2018), Putri \& Jati (2013), Susilawati \& Budiartha (2013) yang memperoleh hasil penelitian bahwa sanksi pajak dapat mempengaruhi kepatuhan wajib pajak.

\section{SIMPULAN}

Kepatuhan wajib pajak merupakan sikap taat dan patuh yang dilakukan oleh wajib pajak terhadap kewajiban pajaknya. Kepatuhan pajak dipengaruhi oleh faktor-faktor seperti kesadaran wajib pajak, pelayanan fiskus, dan sanksi pajak. Kesadaran wajib pajak berarti niat yang dimiliki wajib pajak yang berasal dari dalam dirinya sendiri untuk mematuhi pajak yang terutang olehnya. Pelayanan fiskus merupakan perlakuan yang diberikan oleh fiskus kepada wajib pajak yang dapat mempengaruhi keinginan wajib pajak untuk membayar pajak. Kualitas pelayanan yang baik tercermin dari kemampuan fiskus dalam memberikan pengetahuan mengenai sistem, mekanisme, ketentuan, dan sanksi pajak uang kemungkinan dapat diperoleh apabila wajib pajak melanggar peraturan pajak. Sanksi pajak diterapkan dengan tujuan untuk membuat wajib pajak patuh dan taat pada peraturan perpajakan. Hasil penelitian menunjukkan bahwa kesadaran wajib pajak, pelayanan fiskus, dan sanksi pajak berpengaruh positif pada 
kepatuhan wajib pajak kendaraan bermotor di Kantor Samsat Bersama Kota Denpasar.

\section{REFERENSI}

Acheampong, O., Debrah, O., \& Yeboah, I. O. (2016). An Assessment of Tax Compliance Level of Small Enterprises in Ghana. European Journal of Business and Management, 8(12), 81-89.

Ajzen, I. (1991). The theory of planned behavior. Organizational Behavior and Human Decision Processes, 50(2), 179-211. https://doi.org/10.1016/0749-5978(91)90020-T

Bandura, A. (1978). Social Learning Theory of Aggression. Journal of Communication. https://doi.org/10.1111/j.1460-2466.1978.tb01621.x

Cahyadi, I. M. W., \& Jati, I. K. (2016). Pengaruh Kesadaran, Sosialisasi, Akuntabilitas Pelayanan Publik Dan Sanksi Perpajakan Pada Kepatuhan Wajib Pajak Kendaraan Bermotor. E-Jurnal Akuntansi Universitas Udayana, 16(3), 2342-2373.

Dewi, A. A. S. I. K., \& Setiawan, P. E. (2016). Pengaruh Kesadaran, Kualitas Pelayanan, Kewajiban Moral, Dan Persepsi Sanksi Perpajakan Pada Kepatuhan Wajib pajak Reklame. E-Jurnal Akuntansi Universitas Udayana, 17(1), 84-111. Retrieved from https://ojs.unud.ac.id/index.php/Akuntansi/article/view/17696

Ester, K. G., Nangoi, G. B., \& Alexander, S. W. (2017). Pengaruh Kualitas Pelayanan Pajak Dan Pengetahuan Wajib Pajak Terhadap Kepatuhan Wajib Pajak Orang Pribadi Di Kelurahan Kleak Kecamatan Malalayang Kota Manado. Riset Akuntansi Going Concern, 12(2), 523-530.

Ilyas, W. B., \& Burton, R. (2013). Hukum Pajak (4th ed.). Jakarta: Salemba Empat. Jatmiko, A. N. (2006). Pengaruh Sikap Wajib Pajak Pada Pelaksanaan Sanksi Denda, Pelayanan Fiskus dan Kesadaran Perpajakan Terhadap Kepatuhan Wajib Pajak ( Studi Empiris Terhadap Wajib Pajak Orang Pribadi di Kota Semarang ). Tesis, 86.

Juventia, N. (2014). Pengaruh Kualitas Pelayanan Dan Pengetahuan Pajak Terhadap Tingkat Kepatuhan Wajib Pajak Orang Pribadi (Studi Survei Pada Kantor Pelayanan Pajak Pratama Bandung Karees). Skripsi. Sarjana Jurusan Akuntansi Fakultas Ekonomi Universitas Widyatama.

Kiriakidis, S. (2015). Theory of Planned Behaviour: the Intention-Behaviour Relationship and the Perceived Behavioural Control (PBC) Relationship with Intention and Behaviour. International Journal of Strategic Innovative Marketing, 03, 40-51. https://doi.org/10.15556/ijsim.02.03.004

Komala, Kirana Cipta., D. (2014). Pengaruh Kualitas Pelayanan Perpajakan terhadap Kepatuhan Wajib Pajak Badan (Studi pada Kantor Pelayanan Pajak Madya Malang). PS Perpajakan, 2(1), 1-9.

Mahardika, I. gusti N. P. (2015). Pengaruh Kualitas Pelayanan Dan Sikap Wajib Pajak Pribadi Di Kpp Pratama Singaraja. Jurnal Jurusan Pendidikan Ekonomi, 5(1), 1-12.

Mardiasmo. (2013). Perpajakan (Revisi). Yogyakarta: Andi. 
Megawangi, C. A. M., \& Setiawan, P. E. (2017). Sosialisasi Perpajakan Memoderasi Pengaruh Kesadaran Wajib Pajak Dan Kualitas Pelayanan Pada Kepatuhan Wajib Pajak Badan. E-Jurnal Akuntansi Universitas Udayana, 19(3), 2348-2377.

Nurkhin, A., Novanty, I., Muhsin, M., \& Sumiadji, S. (2018). The Influence of Tax Understanding, Tax Awareness and Tax Amnesty toward Taxpayer Compliance. Jurnal Keuangan Dan Perbankan, 22(2), 240-255. https:// doi.org/10.26905/jkdp.v22i2.1678

Nurlaela, L. (2018). Effect of Tax Service Quality and Tax Sanctions Againts Vehicle Taxpayer Compliance At the Samsat Office of Garut District. International Seminar \& Conference on Learning Organization, 6, 310-317.

Nurlis, \& Kamil, I. (2015). The Effect of Taxpayer Awareness , Knowledge , Tax Penalties and Tax Authorities Services on the Tax Complience: (Survey on the Individual Taxpayer at Jabodetabek \& Bandung). Research Journal of Finance and Accounting, 6(2), 104-112.

Pratiwi, I. G. A. M. A. M. A., \& Setiawan, P. E. (2014). Pengaruh Kesadaran Wajib Pajak, Kualitas Pelayanan, Kondisi Keuangan Perusahaan, dan Persepsi tentang Sanksi Perpajakan pada Kepatuhan Wajib Pajak Reklame di Dinas Pendapatan Kota Denpasar. E-Jurnal Akuntansi Universitas Udayana, 6(1), 139-153. Retrieved from http://majour.maranatha.edu/index.php/maksi/article/view/628

Purnamasari, D., \& Sudaryo, Y. (2018). The Effect of Knowledge Taxpayer, Moral Taypayer and Tax Sanctions on Taxpayers Compulsory. International Journal of Trade, Economics and Finance, 9(5), 214-219. https://doi.org/10.18178/ijtef.2018.9.5.618

Putri, A. R. S., \& Jati, I. K. (2013). Faktor-Faktor Yang Mempengaruhi Kepatuhan Wajib Pajak Dalam Membayar Pajak Kendaraan Bermotor Di Denpasar. E-Jurnal Akuntansi Universitas Udayana, 2(2011), 1-17. https://doi.org/10.1017/CBO9781107415324.004Rahmawati, R., \& Yulianto, A. (2018). Analysis of the Factors Affecting Individual Taxpayers Compliance. Accounting Analysis Journal, 7(1), 17-24. https://doi.org/10.15294/aaj.v5i3.18411

Razieh Tadayon Nabavi. (2016). Bandura' s Social Learning Theory \& Social Cognitive Learning Theory. In Theories of Development Psychology.

Saad, N. (2014). Tax Knowledge, Tax Complexity and Tax Compliance: Taxpayers' View. Procedia - Social and Behavioral Sciences, 109(1), 1069-1075. https:/ / doi.org/10.1016/j.sbspro.2013.12.590

Savitri, E., \& Musfialdy. (2016). The Effect of Taxpayer Awareness, Tax Socialization, Tax Penalties, Compliance Cost at Taxpayer Compliance with Service Quality as Mediating Variable. Procedia Social and Behavioral Sciences, 219, 682-687. https://doi.org/10.1016/j.sbspro.2016.05.051

Suriambawa, A., \& Setiawan, P. E. (2018). Sosialisasi Perpajakan Memoderasi Pengaruh Kesadaran Wajib Pajak dan Sanksi Perpajakan Pada Kepatuhan WPOP. E-Jurnal Akuntansi Universitas Udayana, 25(3), 2185-2211. 
Susilawati, K. E., \& Budiartha, K. (2013). Pengaruh Kesadaran Wajib Pajak, Pengetahuan Pajak, Sanksi Perpajakan dan Akuntabilitas Pelayanan Publik pada Kepatuhan Wajib Pajak Kendaraan Bermotor. E-Jurnal Akuntansi Universitas Udayana, 4(2), 345-357.

Suyanto, S., \& Trisnawati, E. (2016). The Influence of Tax Awareness Toward Tax Compliance of Enterpreneurial Taxpayers and Celengan Padjeg Program as A Moderating Variable: A Case Study At The Pratama Tax Office of Wonosari Town. Inferensi, Jurnal Penelitian Sosial Keagamaan, 10(1), 47-68. https://doi.org/10.18326/infsl3.v10i1.4768

Tiraada, T. A. M. (2013). Kesadaran Perpajakn, Sanksi Pajak, Sikap Fiskus terhadap Kepatuhan WPOP di Kabupaten Minahasa Selatan. Jurnal Emba, 1(3), 999-1008.

Utama, I. W. M. (2013). Pengaruh Kualitas Pelayanan, Sanksi Perpajakan dan Biaya Kepatuhan terhadap Kepatuhan Wajib Pajak. E-Jurnal Akuntansi Universitas Udayana, 2(2), 452-470.

Utami, T., \& Susyanti, S. (2018). Economic and Psychological Approach to Increase Tax Compliance in Micro, Small And Medium Enterprises. Jurnal Akuntansi Dan Investasi, 19(1), 54-63. https://doi.org/10.18196/jai.190191

Wicaksono, M., \& Lestari, T. (2017). Effect of Awareness, Knowledge and Attitude of Taxpayers Tax Compliance for Taxpayers in Tax Service Office Boyolali. International Journal of Economics, Business and Accounting Research (IJEBAR), 1(01), 12-25. https://doi.org/10.29040/ijebar.v1i01.236

Widawati. (2017). Pengaruh Kualitas Pelayanan Perpajakan, Pengetahuan Peraturan Perpajakan, Sosialisasi Perpajakan Dan Sanksi Pajak Terhadap Kepatuhan Wajib Pajak (Studi Empiris Wajib Pajak Orang Pribadi Di Kpp Pratama Boyolali). Skripsi. Sarjana Jurusan Akuntansi Fakultas Ekonomi dan Bisnis Islam Institut Agama Islam Negeri Surakarta.

Widnyani, I. A. D., \& Suardana, K. A. (2016). Pengaruh Sosialisasi, Sanksi, dan Persepsi Akuntabilitas terhadap Kepatuhan Wajib Pajak dalam Membayar Pajak Kendaraan Bermotor. E-Jurnal Akuntansi Universitas Udayana, 16(3), 2176-2203.

Wijaya, S. (2019). Jurnal Manajemen Indonesia Taxpayer Attitude on the Elimination of Tax Sanction and Taxation Awareness toward Taxpayer Compliance in Yogyakarta. Jurnal Manajemen Indonesia, 19(1), 71-79.

Winerungan, O. L. (2013). Pengaruh Pemanfaatan Aplikasi E-SPT Masa PPN Terhadap Tingkat Kepatuhan Wajib Pajak (Studi Pada Kantor Pelayanan Pajak (KPP) Pratama Surabaya Genteng). Jurnal Emba: Jurnal Riset Ekonomi, Manajemen, Bisnis Dan Akuntansi, 1(3), 960-970. https:/ / doi.org/ISSN 2303-1174 